\title{
TUdósíTÁS A NEVELÉSTUdOMÁNYI EgYESÜLET HARMADIK KONFERENCIÁJÁRÓL
}

\section{TORGYIK JUDIT}

\author{
a Kodolányi János Főiskola \\ föiskolai tanára \\ jtorgyik@uranos.kodolanyi.hu
}

A Neveléstudományi Egyesület 3rd International Conference for Theory and Practice in Education: Intercultural Communication, Multicultural Education címmel 2010. május 27-29-e között nemzetközi konferenciát tartott Békéscsabán, melynek az volt a különlegessége, hogy négy kontinens 18 országából jelentkeztek résztvevők a rendezvényre. Ilyen nagy nemzetközi érdeklődéssel tudomásunk szerint az utóbbi években még nem volt neveléstudományi konferencia Magyarországon, ezért érdemesnek tartjuk arra, hogy a szélesebb szakmai közönség előtt is részletesebben beszámoljunk róla. A konferenciára Európa különböző országain kívül Észak-Amerikából is érkezett több előadó, valamint Ázsiából és Afrikából is megjelentek pedagógiai szakemberek a konferencián. A rendezvényre több mint 120-an regisztráltak a neveléstudomány és az andragógia különböző szakterületeiröl, s be kell vallani, hogy a nagyfokú nemzetközi figyelem magukat a szervezőket is meglepte. Néhány ország a résztvevők közül: USA, Dél-Afrika, Ghána, Tajvan, Nagy-Britannia, Németország, Románia, Törökország, Indonézia, Szerbia, Macedónia, Albánia stb.

Néhány szóval érdemes először a szervezőkről szólni. A Neveléstudományi Egyesület 2005-ben jött létre, azzal a céllal, hogy a neveléstudomány területén müködők szakmai fejlődését, tudományos pályáját, professzionális előrejutását segítse. Ez a civil szervezet leginkább a pályakezdők, a PhD-hallgatók, a tanársegédek és az adjunktusok számára kíván tudományos szereplési lehetőséget biztosítani, szakmai teljesítményük, eredményeik megmutatására lehetőséget adni, nem kizárva természetesen a magasabb beosztásban lévő, már szép karriert befutott - külföldön is elismert akadémiai doktorokat, professzorokat, docenseket, $\mathrm{s}$ a kutatóintézetekben, az oktatásügy igazgatási rendszerében és a közoktatásban dolgozó kollégákat sem. Ezt a célkitüzést az egyesület az éves magyar nyelvü és a nemzetközi idegen nyelvü konferenciák megrendezésén, valamint a Practice and Theory in Systems of Education címü angol nyelvü folyóirat szerkesztésén keresztül valósítja meg folyamatosan, immár öt éve. A konferenciáinkra, melyek sorában ez az ötödik (3 idegen nyelvü, 2 magyar nyelvü), már kezdetektől fogva nagy létszámban jelentkeznek 
a neveléstudomány, az andragógia és a szakmódszertanok képviselői a különböző felsőoktatási intézményekből és más szakmai szervezetektől is.

Jól ismert tény, hogy a doktori iskolákban a PhD-hallgatók számára tanulmányaikhoz kötelezően előírt feladat konferencia-előadások, szakmai publikációk megléte, melyek közt nagyobb elismertségnek, értéknek örvendenek az idegen nyelvü előadások és tudományos írások. Erre azonban külföldi környezetben nem mindenkinek van lehetösége, módja - és valljuk meg pénze sem -, ezért döntöttek úgy az egyesület vezetöi, hogy angol és német nyelvü konferenciákat itthon is szerveznek. Az első ilyen céllal megrendezett nemzetközi konferenciára ugyan Ausztriában, Fürstenfeldben került sor, ahol még számos magyar résztvevő volt, de a második, különösen a harmadik konferencián már nagy számban külföldről érkezett résztvevőket is lehetett találni. Sőt, a legutóbbi, jelen beszámoló tárgyát képező, harmadik, nemzetközi konferencián több külföldi előadó volt, mint magyar állampolgár.

A harmadik nemzetközi konferencia első napján a plenáris előadását a Washingtonból érkezett Azra Kacapor Nurcic, a Világ Bank munkatársa tartotta. Az előadó, mielött a Világ Banknál kezdett volna dolgozni, peremhelyzetben lévő gyerekekkel és fiatalokkal foglalkozott Bosznia-Hercegovinában, - ahonnan származik - majd Közel-Keleten, Ázsiában és Latin-Amerikában gyerekek számára szervezett, áldozatvédelemmel, az alternatív pedagógiával foglalkozó programok tervezésében vett részt. Az előadása az oktatásügyet globálisan érintő problémákra hívta fel a figyelmet, úgymint az analfabétizmus, és az iskolából való idő előtti kimaradás kérdései és várható következményei.

A plenáris előadó arról beszélt, hogy miközben az oktatásügy sokat fejlődött az elmúlt évtizedekben, addig még napjainkban is világszerte megközelítőleg 115 millió gyermek nem jár iskolába, s mintegy 960 millió felnőtt - melynek kétharmada nő írástudatlan, illetve funkcionális analfabéta a világon. Ezek a tények komoly kihívások elé állítják a Föld népességének különböző országait, hiszen az oktatási hiányosságok következményei később a társadalom más területeire is továbbgyürüznek. Legföbb megoldandó problémaként említette: az iskolázásra költhető anyagiak hiányát, a gyenge tudású, rosszul felkészült oktatók jelenlétét, a tanítás hiányzó tárgyieszközbeli feltételeit, a szülőkkel és a hátrányos helyzetü közösségek tagjaival való kapcsolat problémáit, a lányok kulturális és intézményi okokból hátrányos helyzetbe szorítását a tanulásban, a többségi kultúrától eltérő diákok igényeinek figyelmen kívül hagyását az iskolában. $\mathrm{S}$ a természeti katasztrófák, háborús konfliktusok hatását, melynek következtében számos gyermek általános iskolai tanulmányai kényszerből abbamaradnak, megnehezítve későbbi életesélyeiket. Az előadó a megoldás lehetőségei közt kiemelte, hogy nemzetközi szinten növelni kell az oktatás minőségét, a helyi környezetet rá kell venni az iskolai körülmények javítására, a szülöket az iskola támogatására, illetve magukat a felnőtteket is az elmaradt tanulmányok pótlására. 
A konferencián 21 szekcióban folyt munka, így például az oktatáspolitika, a speciális szükségletekkel rendelkezők kérdései, a nyelvoktatás és az egészségnevelés is külön szekciót kapott, melyek mindegyikét lehetetlen vállalkozás lenne sorra venni, azonban érdemes egyet-egyet kiemelni közülük.

A Labour Market címet viselő szekció a munkaerőpiac és a képzés világának aktuális kérdéseivel foglalkozott, magyar és nemzetközi kitekintésben érintve a témát. A szekciót Benkei Kovács Balázs (ELTE PPK PhD hallgatója) vezetette. ${ }^{1}$ Elsősorban egyetemi szakemberek nézőpontjából ismerhették meg a résztvevők a szakképzési rendszerek müködését és változásait, illetve a reformok szülte újdonságok bevezetésének nehézségeit. Az előadásokat élénk vita követte. Érdekes volt látni, hogy a külföldi résztvevők milyen szívesen kérdeztek, nyilvánítottak véleményt egy-egy témában.

Ebben a szekcióban az első előadó Abdullah Isiklar, az Erciyes Egyetem oktatója volt, aki a törökországi gyakornoki rendszer meghonosításának terén végez kutatásokat, oktatásszociológiai szemszögből. Elmondta, hogy a gyakornoki-rendszer kiépítése komoly ellenállásba ütközik országukban, ami mind a szülők, mind a tanulók véleményének vizsgálatakor megfigyelhetô volt. A szakmunka alacsony presztízse, a végzettség ,alacsony szintje” miatt a tanulók inkább más típusú, elsősorban felsőfokú tanulmányokat kívánnak folytatni.

A második előadó Farkas Éva volt, aki a magyar szakképzési rendszer 2004 és 2006 közötti reformját mutatta be, amelynek fö eredményei a képzés moduláris struktúrájának kialakítása, valamint a kompetencia alapú képzések bevezetése voltak. Az előadó hangsúlyozta, hogy folyamatban lévő reformról van szó, amelynek egyik fontos célja, hogy visszaadja a szakmunkásképzés korábban elvesztett hitelét.

Pappné Cseh Imola prezentációja szintén a szakképzés munka-erőpiaci célirányultságát emelte ki: miszerint a jelenlegi felsőoktatási végzettségek nem szolgálják kellőképpen a munkáltatók igényeit. Ezért a területen további kutatásokra, valamint a működő pályakövetési rendszer megerösítésére van szükség.

Szilágyi Anikó az idegen-nyelvü álláskeresési technikákból leszürt tapasztalatait osztotta meg a hallgatósággal egy esettanulmány bemutatásán keresztül. Példát kaphattunk arról, hogyan lehetséges egy föiskolai kurzus keretén belül az angol nyelv oktatását sikeresen összekapcsolni az álláskeresési kompetenciák fejlesztésével. A kurzus interaktív, videó felvétellel is dokumentált elemei alapján a szakmai és a személyes kompetenciák fejlesztésére is lehetőségük van a tanulóknak.

Kenderfi Miklós a pályatanácsadás fontosságára, és új funkcióira hívta fel a figyelmet az élethosszig tartó tanulás és a globalizáció jegyében: a külföldi munkavállalás megkönnyítésében, és a munkavállalót érő kulturális sokkhatás leküzdésében a jól felkészült pályatanácsadóknak nagy szerepe lesz a közeljövőben.

\footnotetext{
${ }^{1}$ A beszámolóhoz felhasználtam Benkei Kovács Balázsnak, a Labour Market szekció elnökének öszszefoglalóját.
} 
Contact in Culture címü szekcióban ugyancsak érdekes volt a Lancesterből érkezett Chun-Yu Lin előadása, aki a tajvani vegyes házasságokban élők kulturális és nyelvi felkészítéséről készített vizsgálatáról beszélt előadásában. Hasonlóképp figyelemre méltó volt az egészségnevelés szekcióban az amerikai Kaliforniai Egyetemröl, San Fransisco-ból érkezett Osiaeng Hong prezentációja is, aki az USA-ban, a különbözö munkakörben dolgozók (pl. a nagy zajhatásnak kitett tüzoltók) e-learningre alapozott egészségfejlesztési programjáról szólt, melyet az interneten keresztül rögtön élőben is bemutatott a szekció tagjainak.

Végül, de nem utolsó sorban meg kell említeni a konferencia szervezőbizottságának vezetőjét, Karlovitz János Tibort, a Neveléstudományi Egyesület elnökének, a Miskolci Egyetem BTK Tanárképző Intézetének egyetemi docensének nevét, aki hatalmas munkát és időt fektetett a rendezvény megvalósításába. Nem különben Csereklye Erzsébet, az ELTE PPK tanársegédje, a Neveléstudományi Egyesület tagja, aki rendszeres és folyamatos kapcsolatot tartott a résztvevőkkel, időt és energiát nem kímélve komoly feladatot vállalt a program sikeres kivitelezésében. Álljon itt még Kegyes Erika (ME BTK) neve is, aki a német szekcióba jelentkezett előadások megszervezését koordinálta, s Árpási Zoltán (SZTE GK) is említésre kell, hogy kerüljön, aki a megjelentek számára logisztikai kérdésekben állt rendelkezésre. Ezen túl a tizenhét-tagú szervezőbizottság egésze is említést érdemel, akik az előkészítés szakaszában több, hosszabb megbeszélést, ülést tartottak, $\mathrm{s}$ a beérkezett absztraktokat minden esetben két opponens által, megadott szempontok szerint bírálat alá vetették.

A Neveléstudományi Egyesület a jövőben is szeretné tovább folytatni a megkezdett szakmai munkát, remélve, hogy mind többen bekapcsolódnak a következö idegen nyelvü konferenciák programjába a neveléstudomány képviselöi közül, mely alkalmat ad a tudás és a teljesítmény nyilvános megmérettetésére. Az egyesület által szervezett konferenciák amellett, hogy jó lehetőséget teremtenek saját nyelvtudásunk nemzetközi környezetben való gyakorlására, alkalmat adnak eredményeink külföldi szakemberekkel való összemérésre, illetve hasonló érdeklődési körü kutatók, oktatók megismerésére is. A konferencia nagy tanulsága, hogy nem kell szégyenkeznünk szakmai eredmények tekintetben a tőlünk fejlettebb országok képviselői előtt sem.

A páratlanul gazdag rendezvény jó alkalmat teremtett minden résztvevőnek a kapcsolatteremtésre, új szakmai szálak felvételére, az egymástól való tanulásra. A konferencián elhangzott előadásokat a Practice and Theory in Systems of Education (lásd www.eduscience.hu) címü, a Neveléstudományi Egyesület által müködtetett folyóiratban lehet elolvashatni a következő számokban. Míg a konferencia plenáris előadója, Azra Kacapor Nurcic elöadása teljes terjedelmében a konferencia absztrakt kötetében máris elérhető a fent említett egyesületi honlapon. 